\title{
The Acceptance of E-Learning Among ESL Primary School Students During Covid-19
}

\author{
Khairah Nuraishah Haleman 1 (D) $\triangle$, Hamidah Yamat 2 (iD \\ ${ }^{1}$ Fakulti Pendidikan, Universiti Kebangsaan Malaysia, Malaysia \\ ${ }^{2}$ Associate Professor, Fakulti Pendidikan, Universiti Kebangsaan Malaysia, Malaysia
}

$\triangle$ Corresponding Author: Khairah Nuraishah Haleman, E-mail: knuraishah@gmail.com

\section{ARTICLE INFORMATION}

Received: December 08, 2020

Accepted: January 14, 2021

Volume: 3

Issue: 1

DOI: 10.32996/jeltal.2021.3.1.2

\section{KEYWORDS}

E-Learning, Technology

Acceptance Model, English as a

Second Language, Primary School

Students, Covid-19

\section{ABSTRACT}

The past years have seen a strong focus in Malaysia on the increase of infusion of Information Communication Technology (ICT) in educational institutions to stimulate innovations and strengthen global economic competitiveness. The integration of ICT has transformed the Malaysian education system by reshaping the landscape of education, from teacher-centred to learner-centred education. However, the COVID19 crisis has changed the landscape of the education system drastically. The educators have turned their focus on online learning as an alternative means to replace the faceto-face classroom. Therefore, this paper focuses on the investigation on the perception towards e-learning among ESL primary school students. This study also determined the level of acceptance towards e-learning. A set of questionnaires was distributed via Google Form to 100 upper primary students in Sibu, Sarawak. The results revealed that the perception towards e-learning was positive, and the level of e-learning acceptance among ESL primary school students was high due to its features of e-learning, such as flexibility, user-friendliness, and the students' attitude towards using as well as the intention to use in the future. It was recommended that teachers should utilize student-friendly digital tools to deliver their teaching and learning materials so that the students, especially at the primary level find it easy and enjoy learning English via e-learning.

\section{Introduction}

When the World Health Organization (WHO) declared COVID-19 a global pandemic (WHO, 2020) on 11th March 2020, governments all around the world, including China, Japan, Italy, Australia, New Zealand, and Indonesia, enforced total lockdown or partial lockdown to curb the spread of the virus. Similarly, the Malaysian government immediately implemented a Movement Control Order (MCO), restricting the citizens' movement and encouraging practice good hygiene and social distancing. The COVID-19 pandemic has caused significant impacts in many sectors, including education, leading to schools and universities' total closure, which has affected more than 5 million students in Malaysia (Harian Metro, 2020). To deal with schools and universities' closure, educators have embarked on online learning as a replacement to ensure lessons continue. Li and Lalani (2020) reported a significant rise in online learning, whereby teaching was conducted remotely via digital tools such as Google Classroom due to the closure of schools and universities worldwide. Online learning or best known as electronic learning (elearning), is considered the most appropriate learning approach during the outbreak. Most educators have adopted and utilized electronic teaching modes from virtual conferencing via Zoom and Google Meet, sharing teaching and learning materials via WhatsApp, Telegram, and Google Suites such as Google Classroom, Google Drive, Google Forms, and Google Slides.

However, the COVID-19 pandemic broke out at a time when most education systems around the world were unprepared to make use of the potential of digital technologies. The implementation of e-learning during the outbreak has not been smooth sailing for some students and educators. Teoh (2020) reported that the most significant challenges online learning in Malaysia were the lack of devices in households and poor internet access. Ministry of Education (MOE) conducted a survey, which involved 670,000 parents and 900,000 students, found that about $6 \%$ to $9 \%$ of the students owned personal computers and laptops at home. Meanwhile about $46.5 \%$ of students owned smartphones, and a total of $36.9 \%$ of students nationwide do not have any

K C AL-KINDI CENTER $\mathbf{R}$ FOR RESEARCH AND $\mathbf{R}$ DEVELOPMENT Your gateway to world-class research

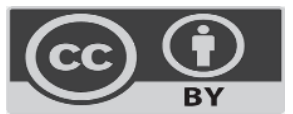

Published by Al-Kindi Center for Research and Development. Copyright (c) the author(s). This open access article is distributed under a Creative Commons Attribution (CC-BY) 4.0 license 
electronic devices (Harian Metro, 2020). Based on the survey, the number of device ownerships for online learning in Malaysia is relatively low compared to students from other countries. The results also indicate that that not all students were ready to learn remotely using digital technologies. On contrary, 95\% of the students in Denmark, Austria, Lithuania, Iceland, and Switzerland own at least a computer for online learning (Ikeda, 2020). The reality of online learning in Malaysia is that teachers, parents, and students are still grappling with home-based online learning due to insufficient equipment, lack of training, and an unfavourable environment (Hamid \& Khalidi, 2020). According to Kim (2020), many students, especially at the primary level, have limited experience with digital technologies such as computers and require parental supervision for online learning. While today's students are introduced to technology at a young age, students are experiencing difficulties transitioning to e-learning because there is no face-to-face or human interaction between teachers and students due to abrupt shift in learning approach (Dong et al., 2020).

Some researchers (Gamble, 2018; Rentler \& Apple, 2020) have revealed that the challenges in delivering online teaching and learning stem from poor consideration on how students perceive and participate in the process of online learning. Such an adhoc implementation of e-learning could result to poor learning outcomes or student engagements (Heggart \& Yoo, 2018). It is unlikely the system's fault but more about the little knowledge of how online learning works. Studies conducted by ZuvicButorac et al. (2011) indicated that monitoring students' satisfaction is essential to ensure the implementation of e-learning remains effective, feasible and viable. Numerous empirical studies have been conducted to examine the students' perception, attitude and acceptance towards different e-learning environments over the years (Dizon, 2016; Fageeh, 2015; Liaw, 2008; Solak \& Cakir, 2014; Tan, 2015). There is little to no research within the ESL context investigating Malaysian primary school students' acceptance of e-learning. There is a need to examine whether the students accept e-learning as a learning approach during the pandemic. To fill this research gap, this study aims to answer the following research questions:

1. What is the level of e-learning acceptance among ESL primary school students?

2. What are ESL primary school students' perceptions of perceived usefulness, ease of use, attitude and behavioural intention to use e-learning?

The rest of the paper is structured as follows. The literature reviews on Technology Acceptance Model (TAM) and e-learning are presented in the Section 2. Then, the research methodology which includes research design, sampling, instrumentation, procedures, and data analysis used in this study are described in Section 3. Subsequently, the findings are summarised in Section 4 and the findings are discussed elaborately in Section 5. Lastly, implications, limitations and recommendation for future studies are provided.

\section{Literature Review}

\subsection{Technology Acceptance Model}

Research on the acceptance, adoption, and use of technology in education has been studied broadly by scholars, encompassing various theories and models into the studies (Alharbi \& Drew, 2014; Kim \& Lee, 2016). The framework of this research adapted from the Technology Acceptance Model (TAM) developed by Davis (1989) seeks to investigate the acceptance of e-learning among ESL primary school students. Fred D. Davis developed Technology Acceptance Model (TAM) in 1986, is a validated theoretical model to explain and predict the user's acceptance of the technology system (IS) (Chang et al., 2012; Davis, 1989). It also helps to elucidate why individuals accept or reject a technology system. Furthermore, this model's fundamental is to provide a foundation for tracing external variables affecting the beliefs, attitudes, and intention to use technology. In attaining the goals of the Technology of Acceptance Model, previous studies suggest scholars identify fundamental factors to technology acceptance related to cognitive and affective (Davis, 1989)

The two cognitive perceptions assumed in this model related to the technology system's acceptance are perceived usefulness and ease of use. The model further assumes that the two perceptions affect the individual's attitude toward using the technology. The individual's behavioural intention to use the technology is influenced by perceived usefulness and user's attitude towards using the technology (Alharbi \& Drew, 2014; Lee et al., 2009). Besides, Technology Acceptance Modul postulates that perceived usefulness and perceived ease of use are influenced by external factors and concurrently influence the individual's behavioural intention to use and actual usage (Davis 1989; Davis et al. 1989) Figure1 shows the Technology Acceptance Model developed by (Davis et al. 1989) 


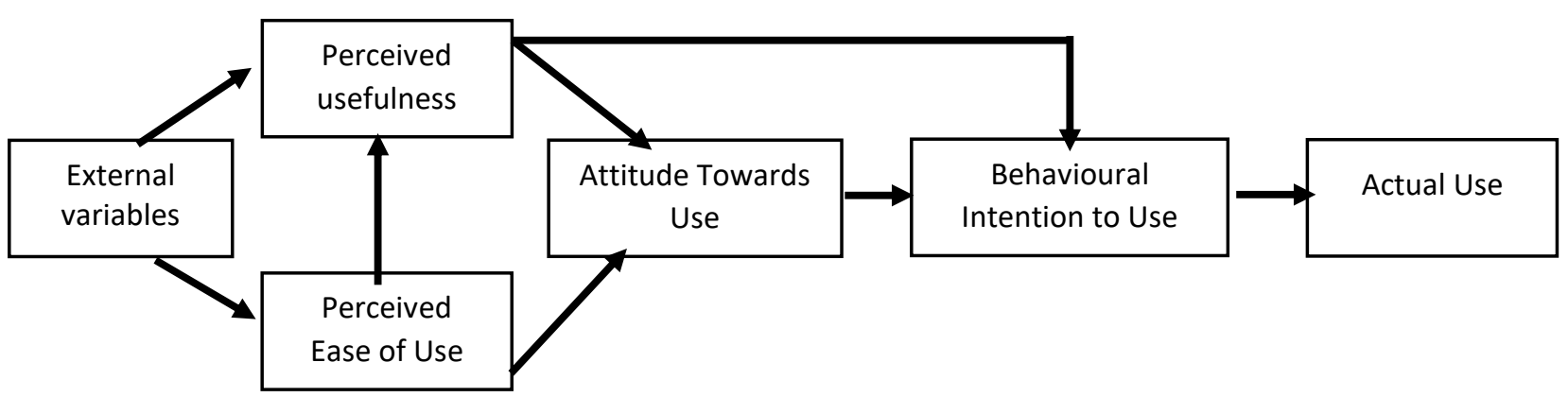

Figure 1.0: Technology acceptance model (Davis et al. 1989)

Technology acceptance is defined as an individual's willingness to accept, adopt, and use a particular technology that can be categorized into behaviour acceptance and attitude acceptance (Arning \& Ziefle, 2007). According to Chang et al. (2012), technology acceptance indicators include perceived usefulness, perceived ease of use, attitude towards use, and behavioural intention to use. However, since the data is self-assessed, it cannot measure actual use responded by users. Therefore, numerous Technology Acceptance Model related studies abandoned the actual use as a pointer of technology acceptance (Scherer et al., 2019).

For decades, many researchers have conducted numerous studies on integrating new technologies in language education to predict their acceptance of the technology. For instance, Kim and Lee (2016) did a research using structural equation model (SEM) to examine Korean students' acceptance and usage mobile-assisted language learning (MALL) and investigate the related determinants that affect MALL usage. According to their results, the key constructs: self-efficacy, M-learning interactivity, content reliability, perceived enjoyment, perceived usefulness, perceived ease of use, attitude, and behavioural intention to use showed significant relationships with one another and impacted students' intention to use. The results of the study also showed that the path coefficient between the constructs were statistically significant. However, the path from self-efficacy and interactivity of MALL to perceived usefulness was not significant. It can be implied that the Korean students were apprehensive of the usefulness MALL as a language learning tool. The researchers concluded that the Technology Acceptance Model was a useful theoretical model to explain and predict students' behavioural intention to use mobile assisted language learning (MALL).

Meanwhile Yeou (2016) also did a similar research with SEM to investigate the acceptance of Moodle among Moroccan students. However, his findings contradict the findings of Kim and Lee (2016). The results showed that the path for computer self-efficacy had a strong direct effect on perceived usefulness, perceived ease of use, and attitude towards use. Computer self-efficacy is considered an intrinsic motivation and plays an important role in affecting intention to use Moodle. However, the researcher noticed that perceived ease of use had weak direct effect on attitude. Yeou (2016) concluded that perceived ease of use did not affect students' attitude towards Moodle. Moreover, in a study conducted at private vocational college, researchers Wan Azli et al. (2018) reported that the mean scores of perceived usefulness and perceived ease of use were high. The result indicates that most of the respondents showed positive perception of mobile assisted language learning (MALL). It was reported that the incorporation of MALL in language classroom offer the learners the access to huge learning resources and provide ample opportunities to try plenty of activities. These findings were congruent with Taat and Francis (2020) who conducted a study at teacher education institute study. The researcher found that the level of acceptance among pre-service teachers was high due to the several factors. The usability, convenience, system quality, lecturer characteristics, technical support and information quality influenced the students' acceptance. Similar study was conducted by Gamble (2018) who found that the level of acceptance towards Google Sites as a Course Management System (CMS) was moderate. It was found that attitude towards use had the highest mean of all constructs. The researcher concluded that Japanese EFL students had positive attitudes towards Google Sites although they had no previous experience using it.

\subsection{E-Learning}

Electronic learning (e-learning for short) has been broadly used in education since the mid-1990s (Lee et al., 2009). The term elearning is often used synonymously with computer-assisted instruction, Web-based learning, online learning, Internet-based learning or distributed learning (Valverde-Berrocoso et al., 2020). Engelbrecht (2005) perceives e-learning as the distribution of learning and teaching materials through various technologies, such as audio/videotape, interactive tv, CD ROM, the Internet, and Intranet. Other researchers like Masrom (2007) see e-learning as any form of education assisted by the Internet and its technology tools and uses the World Wide Web (www) to support active learning and deliver course content. 
Horton (2012) simplifies e-learning as the use of electronic technologies to create learning experiences. It includes the use of elearning tools and platforms to promote efficient delivery of teaching and learning whereby the students and teacher can engage in knowledge construction and transfer, collaboration and training to enhance the values to the individuals or educational organisations (Hiltz \& Turoff, 2005; Hošková-Mayerová \& Rosická, 2015). According to Horton (2012), e-learning manifests in several forms, such as learning games and simulations, mobile learning, social learning, virtual classroom courses, and standalone courses. The advantage of e-learning is its capacity to provide the flexibility of time and place, allowing the educational institutions and their students to deliver and receive learning materials more (Amer et al., 2013). Based on the definition used in the previous studies, for this study, e-learning is defined delivery of teaching and learning materials that utilize various digital tools such as WhatsApp, Telegram, Google Classroom, Google Meet and YouTube.

Several studies have been conducted and many scholars have written about the benefits and advantages in the past few years. A study conducted in EFL university students in Jordan, researchers Albashtawi \& Al Bataineh (2020) found that Google Classroom had a positive impact on reading and writing skills. It was reported that there was significant difference of mean score in pre-test and post-test in reading and writing test. The improvements in reading and writing performance are due to several factors such as the effective implementation of Google Classroom intervention, the long period of the intervention, and the flexibility and simplicity of Google Classroom.

Similar study was conducted by Heggart and Yoo (2018) on integrating Google Classroom in one of tertiary institutions in United State of America. The results showed that most of the students perceived Google Classroom as useful and easy to access the learning materials. It was also reported that Google Classroom provides positive learning atmosphere which allow them to engage dynamically with the learning content and experiences. Similar findings were found in Mutambik (2018). The researcher conducted a case study to investigate the perception on the role of e-learning. The findings suggest that e-learning promotes flexible interactive, and independent learning as well as enhance language skills.

Meanwhile, Aljaser (2019) found that students in the e-learning environment had better performance than those in traditional classrooms. The delivery of learning content in the form of texts, images, videos, and audios attracts students' attention to the lesson's content. The researcher noted that the students' attitude towards learning English in the e-learning environment has improved and increases motivation to learn.

motivation for learning has increased

Besides that, in a study conducted in South Korean university, researchers Robinson et al. (2017) found that students expressed favour for Blackboard because of its flexibility as it allows students to work at their own pace. It was also reported that the students' reading and listening skills improved, but their speaking skills were stagnant as there was no interaction in Blackboard activities. The researcher concluded that the Japanese students perceived Blackboard as not helpful in improving their language skills. Similar findings were found in Dong et al. (2020), who conducted a study on Chinese parents' perspective on their children's online learning during the COVID-19 pandemic. It was reported that Chinese parents preferred a traditional learning environment compared to online learning. This is because online learning lacks a learning atmosphere in which generates fewer learning outcomes. The researcher also reported that the Chinese parents had slightly positive perceptions of the impact of online learning on their children's learning. However, it also highlighted that parents viewed online learning as inconvenient, time-consuming, and challenging as their children did not have sufficient self-control. Generally, the parents negatively perceived online learning and preferred traditional educational environments due to inadequate professional knowledge to teach their children.

\section{Methodology}

\subsection{Research Design}

This research employed a quantitative approach that utilized survey questionnaires to investigate ESL primary school students' perception of perceived usefulness, ease of use, attitude towards use, behavioural intention to use e-learning, and the level of acceptance of e-learning among ESL primary school students. A survey research design is widely used to explain the population's characteristics, opinions, behaviours, or attitudes (Creswell, 2013).

\subsection{Population and Sample}

The study took place at a national school in Sibu, Sarawak. Currently, the researcher is an English language teacher at the school. The school has approximately 700 students enrolled, ranging from pre-school to Year 6 . It is costly to conduct a survey to all students, and therefore, the respondents' scope was narrowed down and focused on Level 2 students. The respondents represent the population of Level 2 students at this particular national school where the study was conducted. The respondents 
of this research were 100 ESL primary school students, aged between 10 to 12 years old. Most of the students' first language is Iban language, Malay language, and Melanau dialect.

The convenience sampling, one of the non-probability sampling techniques, was used to identify this research's respondents (Neuman, 2014). The sample was chosen because the respondents were available and reachable throughout the study, which was conducted during the pandemic. Hence, it enabled data collection to be gathered efficiently despite time constraints.

\subsection{Instrumentation}

A set of questionnaires was adapted from Davis (1989, 1993), and previous literature using Technology Acceptance Model (Alharbi \& Drew, 2014; Chang et al., 2012; Wan Azli et al., 2018). The questionnaire consists four parts and has a total of 12-items to be answered. The measurement items in Part A to D (Question 1 to 12) items include perceived usefulness (4 items), perceived ease of use ( 4 items), attitude toward use ( 2 items), and behavioural intention to use ( 2 items). These parts required respondents to rate their level of agreement and disagreement with the statements based on a 5-point Likert scale ranging from 1 (Strongly Disagree), 2 (Disagree), 3 (Neutral), 4 (Agree), and 5 (Strongly Agree).

Two experts reviewed the questionnaire to confirm that statements for each item were clear and described properly. A pilot study was conducted to determine the instrument's validity and reliability before implemented in the current research. The reliability assessment for this pilot study was based on Cronbach's alpha coefficients. The result obtained from the Cronbach's alpha coefficient test showed that the questionnaire's internal consistency in questionnaire is .968. Vaske et al. (2017) suggest that if the instruments have a Cronbach's Alpha of more than 0.7 , then the instrument is considered reliable and acceptable.

\subsection{Procedure}

First, the researcher sought permission to collect data pertaining the research from the school headmaster. Once the permission to conduct the research was granted, the class teacher on behalf the researcher, distributed the online consent letter to respondents' parents and guardians through WhatsApp. The researcher then shared the link to the survey to all English teachers through WhatsApp to be shared with their students. The data was collected via Google Form due to several constraints faced during Movement Control Order (MCO). Google Form also allows an unlimited number of respondents, and the responses of the survey are automatically gathered in Google Spreadsheet (Kunicki et al., 2019). Google Form is chosen as a platform to circulate the survey questionnaire because it is flexible and accessible to all students. Everyone has to adhere to Standard Operational Procedures (SOP) imposed during the MCO, such as social distancing.

\subsection{Data Analysis}

The data gathered from Google Spreadsheets were transferred to IBM SPSS Statistics Version 25 to analyse the data. Descriptive statistics using mean and standard deviation were employed to answer the research questions: the perception towards elearning and the level of e-learning acceptance. In line with most studies, the researcher categorized the level of interpretation via Best \& Kahn (2006) procedure as follows:

$$
\frac{\text { Highest Score }- \text { Lowest Score }}{\text { Number of Levels }}=\frac{5-1}{3}=1.3
$$

Figure 2: Mean Score Formula

Based on this procedure, the obtained mean scores were interpreted according to three levels, as shown in Table $\mathbf{1 .}$

Table 1: Mean Scores Interpretation

\begin{tabular}{cc}
\hline Mean Scores & Level of Interpretation \\
\hline $1.00-2.33$ & Low \\
$2.34-3.67$ & Moderate \\
$3.68-5.00$ & High \\
\hline
\end{tabular}

\section{Results}

\section{RQ 1: What is the level of e-learning acceptance among ESL primary school students?}

To answer the second research question, the items were computed into four variables: perceived usefulness, perceived ease of use, attitude towards using and behavioural intention to use. Table 6 below is a summary of the computed means of all the items according to variables. 
Table 6: Level of E-learning Acceptance

\begin{tabular}{lccc}
\hline Constructs & Mean & Std. Deviation & Level \\
\hline Perceived Usefulness & 3.96 & 0.631 & High \\
Perceived Ease of Use & 4.17 & 0.528 & High \\
Attitudes Towards Use & 3.95 & 0.904 & High \\
Behavioural Intention To use & 3.82 & 0.854 & High \\
\hline
\end{tabular}

As illustrated in Table 6, the mean scores of four variables fell in the range of 3.67 to 5.00 . Perceived usefulness and perceived ease of use reported mean scores of $3.96(S D=0.631)$ and $4.17(S D=0.528)$. Meanwhile, the mean score of attitudes towards using is $3.95(S D=0.904)$ and the mean score of behavioural intention to use is $3.83(S D=0.854)$. The study results revealed that the level of e-learning acceptance among ESL primary school students is high.

\section{RQ2: What is ESL primary school students' perceptions on perceived usefulness, perceived ease of use, attitude and behavioural intention to use e-learning?}

To answer the first research question, the researcher will focus on the percentage of each item to investigate perceived usefulness, perceived ease of use, attitude and behavioural intention to use e-learning among ESL primary school students. The findings are tabulated and presented according to the variables.

\section{Perceived Usefulness}

Table 2 presents the respondents' responses on perceived usefulness (PU) in terms of frequency and percentage

Table 2 Frequency and Percentage of Perceived Usefulness

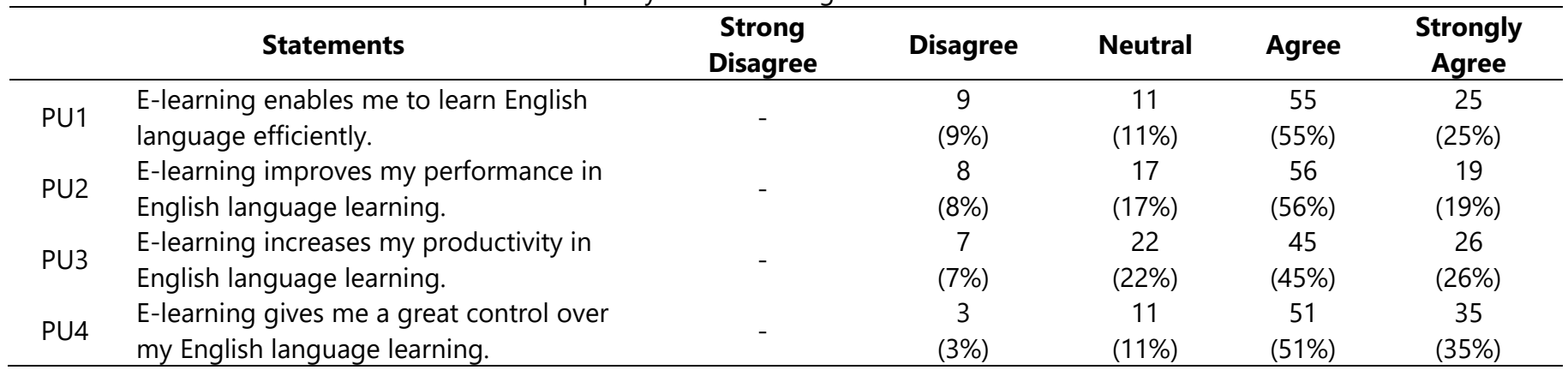

Table 2 presents a staggering number of $80 \%$ respondents believed that e-learning enables them to learn English language efficiently. The majority of the students agreeing that students were learning English in a fun, interactive and systematic environment. About $9 \%$ responded that they did not learn efficiently via e-learning. The findings also reveal that $75 \%$ ) of the respondents perceived that e-learning is useful in improving their English language learning performance. About $17 \%$ respondents were neutral, indicating that no changes in their academic achievement. Meanwhile, $8 \%$ responded disagree towards the same statement, which implies that the students were yet to perceive that e-learning improves their academic performance.

Correspondently, it is also revealed that $71 \%$ of the respondents supported the idea of e-learning had positively increased their productivity in learning English. The result infers that students were becoming active learners in seeking learning materials or answers to accomplish tasks during the pandemic. Meanwhile, $7 \%$ respondents perceived that e-learning did not influence their learning behaviour. Furthermore, $86 \%$ of the respondents believed that e-learning gives the students greater control over their learning. Only $11 \%$ responded neutral, which implies that the students had no opinion on the statement, while $3 \%$ of the respondents disagree, indicating that they prefer traditional learning methods. From these findings, it can be concluded that the ESL primary school students were becoming independent learners as they could schedule their learning. 
Perceived Ease of Use

Table 3 presents the respondents' responses on perceived ease of use (PEOU) in frequency and percentage.

Table 3 Frequency and Percentage of Perceived Ease of Use

\begin{tabular}{|c|c|c|c|c|c|c|}
\hline & Statements & $\begin{array}{c}\text { Strong } \\
\text { Disagree }\end{array}$ & Disagree & Neutral & Agree & $\begin{array}{c}\text { Strongly } \\
\text { Agree }\end{array}$ \\
\hline PEOU1 & $\begin{array}{l}\text { I find it easy for me to become skillful } \\
\text { at using e-learning to learn English } \\
\text { language. }\end{array}$ & - & $\begin{array}{c}9 \\
(9 \%)\end{array}$ & $\begin{array}{c}11 \\
(11 \%)\end{array}$ & $\begin{array}{c}49 \\
(49 \%)\end{array}$ & $\begin{array}{c}31 \\
(31 \%)\end{array}$ \\
\hline PEOU2 & $\begin{array}{l}\text { I find it easy to use e-learning to } \\
\text { retrieve learning material }\end{array}$ & - & $\begin{array}{c}4 \\
(4 \%)\end{array}$ & $\begin{array}{c}6 \\
(6 \%)\end{array}$ & $\begin{array}{c}34 \\
(34 \%)\end{array}$ & $\begin{array}{c}56 \\
(56 \%)\end{array}$ \\
\hline PEOU3 & $\begin{array}{l}\text { I find it easy to complete and submit } \\
\text { my English homework via e-learning. }\end{array}$ & - & $\begin{array}{c}3 \\
(3 \%)\end{array}$ & $\begin{array}{c}7 \\
(7 \%)\end{array}$ & $\begin{array}{c}46 \\
(46 \%)\end{array}$ & $\begin{array}{c}44 \\
(44 \%)\end{array}$ \\
\hline PEOU4 & $\begin{array}{l}\text { I find it easy to understand English } \\
\text { language lesson delivered by my } \\
\text { teacher through e-learning. }\end{array}$ & - & $\begin{array}{c}8 \\
(8 \%)\end{array}$ & $\begin{array}{c}11 \\
(11 \%)\end{array}$ & $\begin{array}{c}60 \\
(60 \%)\end{array}$ & $\begin{array}{c}21 \\
(21 \%)\end{array}$ \\
\hline
\end{tabular}

Table 3 shows that $80 \%$ of the respondents agreed that they found it relatively easy to become skillful at using e-learning to learn English language, while $20 \%$ responded neutral. The result indicates that the students were acquiring ICT skills effortlessly while using e-learning to learn English language. The findings also reveal that $90 \%$ of the respondents responded positively to find it easy to retrieve learning materials via e-learning. The results indicate that the e-learning is user-friendly, and students couldo download the materials for learning easily. Meanwhile, $4 \%$ perceived negative towards the statement. It indicates that the students found it cumbersome to retrieve the learning materials.

Furthermore, $90 \%$ of the respondents rated agree that they found it relatively easy to complete and submit English homework via e-learning. This indicates that the students used less mental and physical efforts to accomplish tasks. Meanwhile $3 \%$ responded negative towards the same statement. It indicates that some students found it challenging to complete and submit homework via e-learning. Moreover, $81 \%$ of the respondents reacted positively that it is easy to understand English language lesson delivered by their teachers via e-learning. Meanwhile, $8 \%$ responded negatively towards the statement. Hence, it can be concluded that a small group of students was still grappling to understand English lessons via e-learning.

\section{Attitude Towards Using}

Table 4 illustrates the respondents' responses on attitude towards using (ATU) in terms of frequency and percentage.

Table 4 Frequency and Percentage of Attitude Towards Use

\begin{tabular}{|c|c|c|c|c|c|c|}
\hline & Statements & $\begin{array}{c}\text { Strong } \\
\text { Disagree }\end{array}$ & Disagree & Neutral & Agree & $\begin{array}{c}\text { Strongly } \\
\text { Agree }\end{array}$ \\
\hline ATU1 & $\begin{array}{l}\text { I think learning English language via e- } \\
\text { learning is a good idea. }\end{array}$ & - & $\begin{array}{c}12 \\
(12 \%)\end{array}$ & $\begin{array}{c}20 \\
(20 \%)\end{array}$ & $\begin{array}{c}28 \\
(28 \%)\end{array}$ & $\begin{array}{c}40 \\
(40 \%)\end{array}$ \\
\hline ATU2 & $\begin{array}{l}\text { I think learning English language via e- } \\
\text { learning is an interesting idea. }\end{array}$ & - & $\begin{array}{c}13 \\
(13 \%)\end{array}$ & $\begin{array}{c}19 \\
(19 \%)\end{array}$ & $\begin{array}{c}30 \\
(30 \%)\end{array}$ & $\begin{array}{c}38 \\
(38 \%)\end{array}$ \\
\hline
\end{tabular}

Based on Table 4, the findings reveal that $68 \%$ of respondents agreed that they think e-learning is good for learning English. This indicates that they had a positive attitude towards using e-learning to learn English during the pandemic. Meanwhile, $12 \%$ of the respondents reacted negatively towards the statement. The findings imply that some students prefer to be in a traditional classroom to learn English. Furthermore, it is reported that $68 \%$ of the respondents agreed towards the idea of learning the English language via e-learning is an interesting idea. About $13 \%$ rated disagree. Hence, the findings can be concluded that the students had positive attitudes towards using e-learning to learn English during the pandemic. 


\section{Behavioural Intention to Use}

Table 5 presents the respondents' responses on behavioural intention to use (BI) in frequency and percentage.

Table 5 Frequency and Descriptive of Behavioural Intention to Use

\begin{tabular}{llccccc}
\hline \multicolumn{1}{c}{ Statements } & $\begin{array}{c}\text { Strong } \\
\text { Disagree }\end{array}$ & Disagree & Neutral & Agree & $\begin{array}{c}\text { Strongly } \\
\text { Agree }\end{array}$ \\
\hline \multirow{2}{*}{ B11 } & $\begin{array}{l}\text { I would like to learn English language via e- } \\
\text { learning in the future. }\end{array}$ & 10 & 20 & 30 & 40 \\
& & $(10 \%)$ & $(20 \%)$ & $(30 \%)$ & $(40 \%)$ \\
BI2 $\quad \begin{array}{l}\text { I plan to learn English language via e- } \\
\text { learning in the future. }\end{array}$ & - & 16 & 26 & 36 & 22 \\
& & $(16 \%)$ & $(26 \%)$ & $(36 \%)$ & $(22 \%)$ \\
\hline
\end{tabular}

Based on Table 5, the findings reveal that majority of the students with $70 \%$ of the of respondents, would like to learn English language via e-learning in the future. However, about $10 \%$ of the respondents rated disagree, stipulating they were not looking forward to use e-learning in the future. Similarly, $68 \%$ of respondents exerted positive perceptions of planning to learn English via e-learning in the future. Despite more than half of the respondents agreeing to use e-learning for learning English in the future, this study found that $16 \%$ of the respondents were yet to plan to use e-learning in English language learning in the future.

\section{Discussion}

The findings revealed that the average mean for perceived usefulness was 3.96 which is at high level. E-learning is perceived as a useful approach for learning English language during the COVID-19 pandemic due to several factors, such as enabling students to learn efficiently, improving academic performance, increasing students' productivity and provides opportunities to students to control their learning. It indicates that the use of digital tools such as Google Classroom, Google Meet, WhatsApp, Telegram and Youtube are considered useful, effective and interactive in learning English. These digital tools have the capability to duplicate the face-to-face interaction such as it allows a two-way communication between teachers and students, and students receive feedbacks quickly and effectively. These findings are broadly in line with Mistar and Embi (2016) which the university students perceived WhatsApp as useful tool in learning English due to its attractive features such as sharing information in the form of documents, audios, videos, and images. A complex topic can be explained clearly by uploading videos or using voice recordings via WhatsApp.

Furthermore, the findings suggested that e-learning increases their productivity and improves students' performance in learning English language. The students were transformed from being passive to active learners in their quest to gain knowledge due to the unprecedented pandemic (McKnight et al., 2016; Yen \& Mohamad, 2020). Students would actively search for information or answers on the Internet, rather than waiting for teachers' answers as they know that there are abundant of learning materials can be found and accessed easily on the Internet such as Youtube and Google Classroom. Utilizing these huge amount of learning resources, it provides tremendous opportunities for students to engage deeper and have better understanding of a topic, consequently it improves students' cognitive process. These findings are consistent with Albashtawi and Al Bataineh (2020) who studied the effect of Google Classroom (GC) on reading and writing achievement among EFL Jordanian students. They reported that GC had positive effects on the reading and writing achievement as the post-test effect size of reading and writing test were $53.60 \%$ and $56.77 \%$. Albashtawi and Al Bataineh (2020) noted that the performance was improvement due to several factors such effective execution of Google Classroom during the intervention, and the long period of intervention which influenced the students' performance.

Moreover, another promising finding is that e-learning offers the students greater control of their own learning. This could be due to the advantages of using e-learning, in which it promotes independent and flexible learning among the students. Through e-learning, the students have the access to the learning materials 24 hours/day which offers them the flexibility to learn. They can schedule their learning, revisit the materials, and complete the tasks anytime and anywhere (Dhawan, 2020). These findings are directly in line with previous findings by McKnight et al (2016). The researchers noted that their students were becoming more independent in choosing materials and no longer rely on textbooks and teacher for information. Giving the students control and responsibility in their learning is one of the key elements of a learner-centred approach, in which it also helps to improve learning. Adding on, the findings reveal that the average mean for perceived ease of use was 4.17 , which is at high level. Perceived ease of use is highly influenced by the features of e-learning and the students' digital literacy skills. The flexibility of e-learning enables the ESL students to access the learning materials in Google Classroom, WhatsApp and Telegram, and 
complete their work at their own pace and time. These results corroborate the findings of the previous work in Heggart and Yoo (2018), where the students appreciated the features of Google Classroom as it was easy for them to retrieve the learning materials as well as to submit assignments and participate in the discussion. The students further praised the benefit of Google Classroom in that it can be accessed through various digital devices such as laptops, tablets, and mobile phones.

Another important finding was that majority of the students agreed that they were competent in operating e-learning. This finding indicates that the students did not use much mental and physical effort to operate e-learning. The finding is in accordance with Heggart and Yoo (2018), who found both instructors and students agreed that Google Classroom is easy for them to use and learn to operate. Besides that, most of the students agreed that they had positive learning experience as they had no problems understanding English lessons. During the MCO, most of the lesson was conducted through live streaming such as Youtube, Google Meet, and Zoom. Some teachers went extra mile by creating videos on learning content and upload them on Youtube. Hence, these methods enable students to revisit their learning by watching videos uploaded on Youtube. The findings are in line with Novawan et al (2021), who conducted a study on students' experiences using Youtube to learn English. The researchers found that all participants revealed that they had positive experience with Youtube as it was a practical and innovative approach to improve students' English skills.

In terms of attitude towards using e-learning, the findings revealed that ESL primary school students had positive attitudes towards the idea of e-learning as a suitable learning approach for learning English during the pandemic. E-learning was employed to replace face-to-face interaction, and it received positive responses from the students. The finding ties well with a previous study by Huang et al (2020), who found that the secondary students displayed positive attitudes towards mobile learning during the pandemic. The main reason for their positive attitudes is good facilitation conditions such as access to the equipment and technical support such as Internet access. Aljaser (2019) explained that an e-learning environment that uses an array of images, texts, animation, video, and colours could draw students' attention to the content of the e-learning. Together with its flexibility, it could stimulate students' positive attitudes towards e-learning for learning English. The study's findings also suggest that the ESL primary school students had the intention to use e-learning for learning English in the near future. This could be due to the uncertainties of the future, as the pandemic is still in a dangerous phase (Ho et al., 2020). The only option available for all educational institutions is to adopt online learning (Adedoyin \& Soykan, 2020). Dhawan (2020) asserted that online learning is no longer an option due to the serious outbreak, but it is the best learning approach during this crisis. Hence, the students have to adopt e-learning as it is considered a favourable method to continue the learning process. However, a study conducted by Hartshorn \& McMurry (2020) found that ESL students expressed that having schoolwork was overwhelming and considered "the most difficult challenge during the pandemic" (p.147). The students reported that being unable to talk to teachers and had to be in front of the computer for many hours was difficult and tiring. The researchers indicated that their engagement in English class was affected by the use of technology-mediated communication.

\section{Conclusion}

Technology Acceptance Model (TAM) has a pivotal role in predicting and explaining individuals' acceptance or rejection of new technology. This is particularly fundamental as starting from mid-March 2020, e-learning is implemented abruptly during the outbreak as a replacement to ensure lesson continues. Hence, this study was conducted in a primary school in Sarawak to investigate the students' perception on e-learning and to determine the level of e-learning acceptance among ESL primary school students. in summary, this research revealed that ESL primary school students had had positive perceptions on perceived usefulness, perceived ease of use, attitude, and behavioural intention to use e-learning. This study also concluded that the students showed a high degree of acceptance towards e-learning in terms of perceived usefulness $(M=3.96)$, perceived ease of use $(M=4.17)$, attitude towards using $(M=3.95)$, and behavioural intention to use $(M=3.82)$. Hence, this study's findings imply Ministry of Education, parents, and teachers about the usage of e-learning and understand students' learning behaviour towards a new learning approach. The findings indicate that educators should use student-friendly digital tools to make it easier for students, especially at the primary level, to use and manage their learning. By doing so, the students will find e-learning as useful, and they will continue using them until the pandemic subside. Besides, it is recommended that the learning content should be fun and interactive so that the students enjoy learning via e-learning. Thus, it helps to motivate them to learn during the pandemic.

Nevertheless, the findings of this study should not be generalized to the whole population of Level 2 students in Malaysian national school because it is a small-scale research. Thus, it is recommended that future research should employ a bigger sample size. Similar studies should consider conducting in various national type schools so that comparative studies can be conducted. Besides that, the findings of this study were limited to four variables that determine the acceptance of e-learning. The future research is encouraged to use extended Technology Acceptance Model such as General Extended Technology Acceptance 
Model for E-Learning (GETAMEL) developed by Abdullah and Ward (2016) in order to yield more data on the acceptance or rejection of new technology and factors contribute to the results. More determinants should be measured to analyse external factors that influence the acceptance or rejection of new technology such as perceived enjoyment, perceived experience, computer anxiety, and self-efficacy.

Funding: This research received no external funding

Acknowledgments: All authors contributed equally to the conception and Design of the study.

Conflicts of Interest: The authors declare no conflict of interest.

\section{References}

[1] Adedoyin, O. B., \& Soykan, E. (2020). Covid-19 pandemic and online learning: the challenges and opportunities. Interactive Learning Environments, O(0), 1-13. https://doi.org/10.1080/10494820.2020.1813180

[2] Albashtawi, A. H., \& Al Bataineh, K. B. (2020). The effectiveness of google classroom among EFL students in Jordan: An innovative teaching and learning online platform. International Journal of Emerging Technologies in Learning, 15(11), 78-88. https://doi.org/10.3991/IJET.V15I11.12865

[3] Alharbi, S., \& Drew, S. (2014). Using the Technology Acceptance Model in Understanding Academics' Behavioural Intention to Use Learning Management Systems. International Journal of Advanced Computer Science and Applications, 5(1). https://doi.org/10.14569/ijacsa.2014.050120

[4] Aljaser, A. M. (2019). The effectiveness of E-Learning environment in developing academic achievement and the attitude to learn english among primary students. Turkish Online Journal of Distance Education, 20(2), 176-194. https://doi.org/10.17718/tojde.557862

[5] Amer, A.-A., Ahmad, A.-A., \& Jo, S. (2013). Exploring Students Acceptance of E-learning Using Technology Acceptance Model in Jordanian Universities. International Journal of Education and Development Using Information and Communication Technology, 9(2), 4-18. http://ijedict.dec.uwi.edu/viewarticle.php?id=1617

[6] Arning, K., \& Ziefle, M. (2007). Understanding age differences in PDA acceptance and performance. Computers in Human Behavior, 23(6), 2904-2927. https://doi.org/10.1016/j.chb.2006.06.005

[7] Best, J. W., \& Kahn, J. V. (2006). Research in Education,Tenth Edition (A. E. Burvikovs (ed.); Tenth). Pearson Education.

[8] Chang, C. C., Yan, C. F., \& Tseng, J. S. (2012). Perceived convenience in an extended technology acceptance model: Mobile technology and English learning for college students. Australasian Journal of Educational Technology, 28(5), 809-826. https://doi.org/10.14742/ajet.818

[9] Creswell, J. (2013). Qualitative, quantitative, and mixed methods approaches. In Research design.

[10] Davis, F. D. (1989). Perceived usefulness, perceived ease of use, and user acceptance of information technology. MIS Quarterly: Management Information Systems, 13(3), 319-339. https://doi.org/10.2307/249008

[11] Dhawan, S. (2020). Online Learning: A Panacea in the Time of COVID-19 Crisis. Journal of Educational Technology Systems, 49(1), 5-22. https://doi.org/10.1177/0047239520934018

[12] Dizon, G. (2016). Measuring Japanese EFL Student Perceptions of Internet-Based Tests with the Technology Acceptance Model. Tesl-Ej, 20(2).

[13] Dong, C., Cao, S., \& Li, H. (2020). Young children's online learning during COVID-19 pandemic: Chinese parents' beliefs and attitudes. Children and Youth Services Review, 118(June), 105440. https://doi.org/10.1016/j.childyouth.2020.105440

[14] Engelbrecht, E. (2005). Adapting to changing expectations: Post-graduate students' experience of an e-learning tax program. Computers and Education, 45(2), 217-229. https://doi.org/10.1016/j.compedu.2004.08.001

[15] Fageeh, A. I. (2015). EFL student and faculty perceptions of and attitudes towards online testing in the medium of Blackboard: Promises and challenges. JALT CALL Journal, 11(1), 41-62. http://journal.jaltcall.org/articles/11_1_Fageeh.pdf

[16] Gamble, C. (2018). Exploring EFL University Students' Acceptance of E-learning Using TAM. Kwansei Gakuin University Humanities Review, 22, 23-37.

[17] Hamid, H. A., \& Khalidi, J. R. (2020). Covid-19 and Unequal Learning. Khazanah Research Institute, April, 1-8.

[18] Hartshorn, K. J., \& McMurry, B. L. (2020). The Effects of the COVID-19 Pandemic on ESL Learners and TESOL Practitioners in the United States. International Journal of TESOL Studies, 2, 140-156. https://doi.org/10.46451/ijts.2020.09.11

[19] Heggart, K. R., \& Yoo, J. (2018). Getting the most from google classroom: A pedagogical framework for tertiary educators. Australian Journal of Teacher Education, 43(3), 140-153. https://doi.org/10.14221/ajte.2018v43n3.9

[20] Hiltz, S. R., \& Turoff, M. (2005). Education goes digital: The evolution of online learning and the revolution in higher education. Communication of the ACM, 48(10), 59-64. https://doi.org/10.1145/1089107.1089139

[21] Ho, N. T. T., Sivapalan, S., Pham, H. H., Nguyen, L. T. M., Pham, A. T. Van, \& Dinh, H. V. (2020). Students' adoption of e-learning in emergency situation: the case of a Vietnamese university during COVID-19. Interactive Technology and Smart Education. https://doi.org/10.1108/ITSE-08-2020-0164

[22] Horton, W. (2012). E-Learning by Design (2nd Editio). Pfeiffer.

[23] Hošková-Mayerová, Š., \& Rosická, Z. (2015). E-Learning Pros and Cons: Active Learning Culture? Procedia - Social and Behavioral Sciences, 191, 958-962. https://doi.org/10.1016/j.sbspro.2015.04.702

[24] Huang, F., Lou, Y., Chen, S., \& Guo, J. (2020). Students perceptions of using mobile technologies in informal English learning during the COVID-19 epidemic: A study in Chinese rural secondary schools. Journal of Pedagogical Research, 4(4), 475-483. https://doi.org/10.33902/jpr.2020063786

[25] Ikeda, M. (2020). Were schools equipped to teach - and were students ready to learn - remotely? In PISA in Focus: Vol. No. 108. https://doi.org/https://doi.org/10.1787/4bcd7938-en 
[26] Kim, G., \& Lee, S. J. (2016). Korean Students' Intentions to Use Mobile-Assisted Language Learning: Applying the Technology Acceptance Model. International Journal of Contents, 12(3), 47-53. https://doi.org/10.5392/ijoc.2016.12.3.047

[27] Kim, J. (2020). Learning and Teaching Online During Covid-19: Experiences of Student Teachers in an Early Childhood Education Practicum. International Journal of Early Childhood, 52(2), 145-158. https://doi.org/10.1007/s13158-020-00272-6

[28] Kunicki, Z. J., Zambrotta, N. S., Tate, M. C., Surrusco, A. R., Risi, M. M., \& Harlow, L. L. (2019). Keep Your Stats in the Cloud! Evaluating the Use of Google Sheets to Teach Quantitative Methods. Journal of Statistics Education, 27(3), 188-197. https://doi.org/10.1080/10691898.2019.1665485

[29] Lee, B. C., Yoon, J. O., \& Lee, I. (2009). Learners' acceptance of e-learning in South Korea: Theories and results. Computers and Education. https://doi.org/10.1016/j.compedu.2009.06.014

[30] Liaw, S. S. (2008). Investigating students' perceived satisfaction, behavioral intention, and effectiveness of e-learning: A case study of the Blackboard system. Computers and Education, 51(2), 864-873. https://doi.org/10.1016/j.compedu.2007.09.005

[31] Masrom, M. (2007). Technology acceptance model and E-learning. 12th International Conference on Education, May, $21-24$.

[32] McKnight, K., O’Malley, K., Ruzic, R., Horsley, M., Franey, J. J., \& Bassett, K. (2016). Teaching in a digital age: How educators use technology to improve student learning. Journal of Research on Technology in Education, 48(3), 194-211. https://doi.org/10.1080/15391523.2016.1175856

[33] Mistar, I., \& Embi, M. A. (2016). Students' Perception on the Use of Whatsapp As a Learning Tool in Esl Classroom. Journal of Education and Social Sciences, 4, 96-104. http://jesoc.com/wp-content/uploads/2016/08/Edu-76.pdf

[34] Mutambik, I. (2018). The Role of E-learning in Studying English as a Foreign Language in Saudi Arabia: Students' and Teachers' Perspectives. English Language Teaching, 11(5), 74. https://doi.org/10.5539/elt.v11n5p74

[35] Novawan, A., Alvarez-tosalem, S. M., Wicaksono, J. A., Setiarini, R. B., \& Ismailia, T. (2021). Students ' Experiences of Online English Language Learning by Using YouTube. Advances in Social Science, Education and Humanities Research, 514(ICOSHIP 2020), $220-226$.

[36] Rentler, B. R., \& Apple, D. (2020). Understanding the Acceptance of E-learning in a Japanese University English Program Using the Technology Acceptance Model. 5, 22. https://doi.org/10.34409/apujlr.5.0_22

[37] Robinson, G., Basco, L. M., Mathews, Y., Dancel, R., Princena, M. A., \& Keever, M. J. M. (2017). ESL Student Perceptions of VLE Effectiveness at a University in South Korea. Journal of Language Teaching and Research, 8(5), 847. https://doi.org/10.17507/jltr.0805.02

[38] Scherer, R., Siddiq, F., \& Tondeur, J. (2019). The technology acceptance model (TAM): A meta-analytic structural equation modeling approach to explaining teachers' adoption of digital technology in education. Computers and Education, 128, 13-35. https://doi.org/10.1016/j.compedu.2018.09.009

[39] Solak, E., \& Cakir, R. (2014). Face to face or e-learningin Turkish EFL context. Turkish Online Journal of Distance Education, 15(3), 37-49. https://doi.org/10.17718/tojde.43750

[40] Tan, P. J. B. (2015). English e-learning in the virtual classroom and the factors that influence ESL (English as a Second Language): Taiwanese citizens' acceptance and use of the Modular Object-Oriented Dynamic Learning Environment. Social Science Information, 54(2), $211-228$. https://doi.org/10.1177/0539018414566670

[41] Valverde-Berrocoso, J., del Carmen Garrido-Arroyo, M., Burgos-Videla, C., \& Morales-Cevallos, M. B. (2020). Trends in educational research about e-Learning: A systematic literature review (2009-2018). Sustainability (Switzerland), 12(12). https://doi.org/10.3390/su12125153

[42] Vaske, J. J., Beaman, J., \& Sponarski, C. C. (2017). Rethinking Internal Consistency in Cronbach's Alpha. Leisure Sciences, 39(2), 163-173. https://doi.org/10.1080/01490400.2015.1127189

[43] Wan Azli, W. U. A., Shah, P. M., \& Mohamad, M. (2018). Perception on the Usage of Mobile Assisted Language Learning (MALL) in English as a Second Language (ESL) Learning among Vocational College Students. Creative Education, 09(01), 84-98. https://doi.org/10.4236/ce.2018.91008

[44] Yen, E. L. Y., \& Mohamad, M. (2020). Utilising E-Learning to Assist Primary School ESL Pupils in Learning to Spell during COVID-19 Pandemic: A Literature Review. Creative Education, 11(08), 1223-1230. https://doi.org/10.4236/ce.2020.118091

[45] Zuvic-Butorac, M., Roncevic, N., Nemcanin, D., \& Radojicic, Z. (2011). Blended E-Learning in Higher Education: Research on Students' Perspective. Issues in Informing Science and Information Technology, 8, 409-429. https://doi.org/10.28945/1427 